\title{
EFEK EKSTRAK TANDUK RUSA SAMBAR (CERVUS UNICOLOR) TERHADAP KADAR UREUM DAN KREATININ TIKUS PUTIH (RATTUS NOVERGICUS)
}

\author{
Defriana, Aditya Fridayanti, Laode Rijai \\ Laboratorium Penelitian dan Pengembangan FARMAKA TROPIS Fakultas Farmasi \\ Universitas Mulawarman, Samarinda, Kalimantan Timur \\ email: khawarizm1@yahoo.com
}

\begin{abstract}
ABSTRAK
Telah dilakukan penelitian yang bertujuan untuk menguji keamanan penggunaan ekstrak tanduk rusa sambar (Cervus unicolor) ditinjau dari dosis dan lama pemberian dengan mengukur kadar ureum dan kreatinin dalam darah tikus putih (Rattusnovergicus). Tikus sebanyak 9 ekor dibagi menjadi 3 kelompok yaitu kelompok 1 sebagai kontrol, kelompok 2 perlakuan dosis I dan kelompok 3 perlakuan dosis II. Kelompok kontrol diberi pakan standar dan air suling, Kelompok 2 diberi pakan standar dan dosis sebanyak 1,55 mg/200 g BB. Kelompok 3 diberi pakan standar, dan dosis sebanyak $31 \mathrm{mg} / 200 \mathrm{~g}$ BB. Perlakuan ini dilakukan selama 21 hari. Darah tikus diambil pada hari ke 0, 7, 14 dan 21 untuk dilakukan pengukuran kadar ureum dan kreatinin. Hasil yang diperoleh adalah pemberian ekstrak tanduk rusa sambar tidak berpengaruh terhadap kadar ureum dan kreatinin dalam darah tikus putih sehingga aman untuk digunakan.
\end{abstract}

Kata Kunci: Ekstrak tanduk rusa sambar, Kadar ureum, Kadar kreatinin.

\section{PENDAHULUAN}

Pemanfaatan bahan alam yang memiliki khasiat obat dan digunakan masyarakat sebagai obat tradisional membutuhkan serangkaian pengujian keamanan yang sangat diperlukan sebagai informasi dan peringatan kepada masyarakat tentang keamanan penggunaan obat tradisional. Salah satu bahan alam yang digunakan sebagai obat tradisional adalah serbuk tanduk rusa sambar yang banyak dikonsumsi masyarakat serta telah dipasarkan dalam bentuk kapsul dan dipercaya berfungsi sebagai penambah daya tahan tubuh dan sebagai obat kuat. Namun penggunaannya dimasyarakat masih mengkhawatirkan karena belum ada penelitian ilmiah mengenai keamanan serbuk tanduk rusa sambar terhadap berbagai organ di dalam tubuh.

Tanduk rusa sambar mengandung protein keratin yaitu protein penyusun rambut dan kuku atau tulang. Keratin adalah protein yang mempunyai struktur kompleks, kuat dan kaku serta sulit diuraikan di dalam tubuh sehingga apabila dikonsumsi dalam jumlah yang banyak serta dalam jangka waktu yang lama akan memperberat kerja ginjal dalam proses filtrasi sehingga dikhawatirkan akan menimbulkan kerusakan pada ginjal, serbuk tanduk rusa sambar juga mengandung banyak mineral yang dikhawatirkan akan menimbulkan efek toksik apabila digunakan dalam jumlah yang banyak serta dalam jangka waktu yang lama. Sehingga perlu dilakukan penelitian mengenai keamanan penggunaanya terhadap organ ginjal.Kandungan mineralnya antara lain kalsium, kalium, magnesium, natrium, fosfor, kobalt, tembaga, besi, mangan, dan selenium, sehingga kapsul tanduk ini dapat dipakai sebagai obat perangsang libido (Semiadi dan Nugraha, 2004). 
Ginjal merupakan organ utama
untuk membuang produk sisa metabolisme yang tidak diperlukan lagi oleh tubuh, seperti urea (dari metabolisme asam amino), kreatinin (dari kreatin otot), asam urat (dari asam nukleat), produk akhir pemecahan hemoglobin (seperti bilirubin), dan metabolit dari berbagai hormon. Ginjal membuang banyak toksin dan zat asing lainnya yang diproduksi oleh tubuh atau pencernaan, seperti pestisida, obatobatan dan makanan tambahan(Guyton dan Hall, 2007).

Urea atau ureum merupakan produk akhir proses katabolisme asam amino, keberadaan urea dalam darah (dihitung sebagai Blood Urea Nitrogen, BUN). Pada penurunan fungsi ginjal, kadar nitrogen urea darah (BUN) meningkat. Dengan demikian, pengukuran BUN memberikan petunjuk mengenai keadaan kesehatan ginjal (Corwin, 2009).

Kreatinin adalah suatu metabolit keratin dan dieksresi seluruhnya dalam urin melalui filtrasi glomerulus. Dengan demikian, meningkatnya kadar kreatinin dalam darah merupakan indikasi rusaknya fungsi ginjal (Lu, 2006). Kreatinin serum dianggap lebih sensitive dan merupakan indicator khusus pada penyakit ginjal dibandingkan uji dengan kadar nitrogen urea darah (BUN). Kenaikannya terjadi tidak dipengaruhi oleh asupan makanan ataupun minuman. Kreatinin serum sangat berguna untuk mengevaluasi fungsi glomerulus (Kee, 2008). Oleh karena itu untuk mengetahui keamanan dari penggunaan serbuk tanduk rusa sambar dapat dilakukan dengan tes fungsi ginjal dengan cara pengukuran kadar ureum (BUN) dan kreatinin dalam darah.

\section{METODE PENELITIAN}

\section{Bahan}

Bahan yang digunakan dalam penelitian adalah sediaan serbuk tanduk rusa sambar yang diperoleh dari Kabupaten Penajam Paser Utara, air suling,alkohol $70 \%$,tikus putih sebagai hewan uji dan pelet sebagai pakan tikus.

\section{Peralatan}

Peralatan yang digunakan pada penelitian ini antara lain gelas kimia, labu ukur, cawan porselin, timbangan analitik, timbangan untuk menimbang tikus,spoit, sonde, fotometer semi automatic, dan sentrifuge.

\section{PenyiapanSampelUji}

Penyiapan sampel uji dilakukan dengan cara menimbang sampel sebanyak 4,5 $\mathrm{mg} / 200$ g BB untuk dosis I dan 90 $\mathrm{mg} / 200 \mathrm{~g}$ BB untuk dosis II (sesuai dengan perhitungan dosis) kemudian dilarutkan dengan air suling, diaduk kemudian disaring sehingga dihasilkan ekstrak tanduk rusa sambar dan siap dilakukan pengujian.

\section{Prosedur Pengujian}

Pengujian ini menggunakan 9 ekor tikus putih yang dibagi menjadi 3 kelompok. Kelompok kontrol diberikan air suling, kelompok dosis I diberikan ekstrakdariserbuk tanduk rusa sambar sebanyak $250 \mathrm{mg}$ yaitu dosis yang digunakan masyarakat pada umumnya dan dikonversikan ke dalam dosis tikus sebesar 4,5 mg/200 g BB serta kelompok dosis II diberikan ekstrakdariserbuk tanduk rusa sambar sebanyak $5000 \mathrm{mg}$ yaitu dosis 20 kali lipat dari dosis yang digunakan masyarakat dan dikonversikan ke dalam dosis tikus sebesar $90 \mathrm{mg} / 200 \mathrm{~g}$ BB. Serbuk tanduk rusa sambar yang telah ditimbang kemudian dilarutkan dengan air suling dan disaring sehingga diperoleh ekstrak tanduk rusa sambar. Untuk mengetahui dosis ekstrak yang terdapat pada serbuk tanduk rusa sambar sebanyak $4,5 \mathrm{mg} / 200$ g BB dan $90 \mathrm{mg} / 200 \mathrm{~g}$ BB dilakukan perhitungan kadar air dan berat residu hasil penyaringan sehingga diperoleh dosis ekstrak tanduk rusa sambar pada 
serbuk tanduk rusa sambar sebanyak 4,5 $\mathrm{mg} / 200 \mathrm{~g} \mathrm{BB}$ adalah $1,55 \mathrm{mg} / 200 \mathrm{~g} \mathrm{BB}$ dan $90 \mathrm{mg} / 200 \mathrm{~g} \mathrm{BB}$ adalah $31 \mathrm{mg} / 200 \mathrm{~g}$ BB. Ekstrak tanduk rusa sambar diberikan pada hewan uji (tikus putih) selama 21 hari. Pengujian kadar BUN dan kreatinin dilakukan pada hari ke 0 sebelum perlakuan, hari ke 7, 14 dan 21 setelah perlakuan.

\section{HASIL DAN PEMBAHASAN}

BUN dan kreatinin merupakan buangan metabolisme normal yang diekskresikan melalui urin, sehingga pada keadaan normal kadarnya rendah di dalam darah. Namun, apabila terjadi perubahan pada fungsi ginjal, maka jumlah BUN dan kreatinin yang diekskresikan oleh ginjal menurun sehingga akan terjadi akumulasi kadar senyawa-senyawa tersebut yang berakibat meningkatnya kadarnya di dalam darah. Oleh karena itu, kadar BUN dan kreatinin di dalam darah dapat dijadikan sebagai parameter fungsi ginjal.
Sedikit peningkatan kadar BUN
dapat menandakan terjadinya hipovolemia (kekurangan volume cairan) dan kadar BUN yang rendah mengindikasikan keadaan hidrasi yang berlebihan (hipervolemia) (Kee, 2008). Untuk menilai fungsi ginjal, permintaan pemeriksaan kreatinin dan BUN hamper selalu disatukan (dengan darah yang sama). Kadar kreatinin dan BUN sering diperbandingkan. Jika kadar BUN dan kreatinin meningkat, dicurigai terjadi kerusakan ginjal (peningkatan BUN lebih pesat daripada kreatinin) dan jika kadar BUN meningkat sedangkan kreatinin tetap normal, kemungkinan terjadi uremia non-renal (prarenal). Uremia prarenal terjadi karena gagalnya mekanisme yang bekerja sebelum filtrasi oleh glomerulus. Mekanisme tersebut meliputi penurunan aliran darah ke ginjal seperti pada syok, kehilangan darah, dan dehidrasi serta peningkatan katabolisme protein seperti pada cedera fisik berat, luka bakar dan demam (Sacherdkk., 2004).

Tabel 1. Data Pengukuran Kadar BUN

\begin{tabular}{cccccc}
\hline \multirow{2}{*}{ Perlakuan } & \multicolumn{4}{c}{ Kadar BUN (mg/dL) } \\
\cline { 3 - 6 } Kelompok & Replikasi & Sebelum Perlakuan & Hari ke 7 & Hari ke 14 & Hari ke 21 \\
\hline \multirow{5}{*}{ Kontrol } & 1 & 64,2 & 54,3 & 42,1 & 51,2 \\
& 2 & 66,9 & 52,1 & 37,5 & 50,1 \\
& 3 & 55,9 & 48,7 & 40,4 & 50,2 \\
& $\mathrm{n}_{\text {total }}$ & 187 & 155,1 & 120 & 151,5 \\
& $\mathrm{n}_{\text {rata-rata }}$ & 62,3 & 51,7 & 40 & 50,5 \\
& 1 & 42,2 & 43,6 & 42,5 & 44,8 \\
Dosis I & 2 & 42,3 & 44,9 & 40,2 & 35,7 \\
& 3 & 60,8 & 66,2 & 50,1 & 49,9 \\
& $\mathrm{n}_{\text {total }}$ & 145,3 & 154,7 & 132,8 & 130,4 \\
& $\mathrm{n}_{\text {rata-rata }}$ & 48,3 & 51,57 & 44,27 & 43,47 \\
& 1 & 45,7 & 44,4 & 36,1 & 24,9 \\
Dosis II & 2 & 44,9 & 48,6 & 43,0 & 38,4 \\
& 3 & 45,0 & 47,2 & 42,5 & 29,9 \\
& $\mathrm{n}_{\text {total }}$ & 135,6 & 140,2 & 121,6 & 93,2 \\
& $\mathrm{n}_{\text {rata-rata }}$ & 45,2 & 46,73 & 40,53 & 31,07 \\
\hline
\end{tabular}


Tabel 2. Data Pengukuran Kadar Kreatinin

\begin{tabular}{cccccc}
\hline Kelompok & Replikasi & Sebelum Perlakuan & Hari ke 7 & Hari ke 14 & Hari ke 21 \\
\hline \multirow{5}{*}{ Kontrol } & 1 & 0,5 & 0,5 & 0,5 & 0,5 \\
& 2 & 0,5 & 0,5 & 0,5 & 0,3 \\
& 3 & 0,5 & 0,5 & 0,6 & 0,5 \\
& $\mathrm{n}_{\text {total }}$ & 1,5 & 1,5 & 1,6 & 1,3 \\
& $\mathrm{n}_{\text {rata-rata }}$ & 0,5 & 0,5 & 0,53 & 0,43 \\
& 1 & 0,5 & 0,6 & 0,5 & 0,5 \\
Dosis I & 2 & 0,5 & 0,5 & 0,4 & 0,5 \\
& 3 & 0,5 & 0,6 & 0,5 & 0,5 \\
& $\mathrm{n}_{\text {total }}$ & 1,5 & 1,7 & 1,4 & 1,5 \\
& $\mathrm{n}_{\text {rata-rata }}$ & 0,5 & 0,57 & 0,47 & 0,5 \\
& 1 & 0,5 & 0,5 & 0,5 & 0,5 \\
Dosis II & 2 & 0,6 & 0,3 & 0,5 & 0,5 \\
& 3 & 0,5 & 0,6 & 0,5 & 0,5 \\
& $\mathrm{n}_{\text {total }}$ & 1,6 & 1,4 & 1,5 & 1,5 \\
& $\mathrm{n}_{\text {rata-rata }}$ & 0,53 & 0,47 & 0,5 & 0,5 \\
\hline
\end{tabular}

BerdasarkanTabel 1. terlihat ratarata kadar BUN pada kelompok dosis I dan kelompok dosis II meningkat pada hari ke 7 setelah perlakuan, tetapi kadarnya menurun kembali hingga pengukuran pada hari ke 21. Penurunan kadar BUN tersebut juga terjadi pada kelompok kontrol sehingga tidak terdapat perbedaan antara kelompok kontrol dengan kelompok dosis I dan kelompok dosis II yang berartipenggunaan serbuk tanduk rusa sambar pada dosis $1,55 \mathrm{mg} / 200 \mathrm{~g} \mathrm{BB}$ dan $31 \mathrm{mg} / 200 \mathrm{~g}$ BB pada waktu pemberian hingga 21 hari tidak berpengaruh terhadap kadar BUN tikus putih. Peningkatan kadar BUN yang terjadi pada hari ke 7 setelah perlakuan kemungkinan dikarenakan kondisi hewan uji yang mengalami syok dan kehilangan darah serta dehidrasi saat perlakuan yang menyebabkan penurunan aliran darah ke ginjal sehingga sebagian besar ureum tidak difiltrasi di glomerulus yang mengakibatkan kadarnya meningkat di dalam darah, pada hari ke 14 dan 21 hewan uji telah mampu beradaptasi terhadap kondisi perlakuan sehingga kadar BUN menurun atau mendekati normal.
Berdasarkan Tabel 2. terlihat ratarata kadar kreatinin pada setiap kelompok perlakuan dan lama waktu pengukuran tidak menunjukkan nilai peningkatan yang signifikan dan kadar kreatinin pada setiap kelompok perlakuan berada dalam rentang normal kadar kreatinin tikus putih yaitu 0,2-0,8 $\mathrm{mg} / \mathrm{dL}$. Dengan demikian penggunaan serbuk tanduk rusa sambar pada dosis $1,55 \mathrm{mg} / 200 \mathrm{~g} \mathrm{BB}$ dan $31 \mathrm{mg} / 200 \mathrm{~g} \mathrm{BB}$ selama 21 hari tidak berpengaruh terhadap kadar kreatinin tikus putih.

\section{KESIMPULAN}

Pemberian ekstrak tanduk rusa sambar pada dosis yang digunakan masyarakat selama ini serta pada kenaikan dosis 20 kali lipat dan lama waktu pemberian 21 hari tidak menyebabkan peningkatan yang spesifik terhadap kadar BUN dan Kreatinin tikus putih, sehingga tidak menyebabkan penurunan fungsi ginjal.

\section{DAFTAR PUSTAKA}

1. Corwin, Elizabeth J. 2009. Buku Saku Patofisiologi. EGC: Jakarta.

2. Guyton, A. C. dan John, E. Hall. 2007. Buku Ajar Fisiologi Kedokteran. EGC: Jakarta. 
3. Kee, Joyce LeFever. 2007. Pedoman Pemeriksaan Laboratorium dan Diagnostik. EGC: Jakarta.

4. Lu, Frank C. 2006. Toksikologi Dasar. UI-Press: Jakarta.
5. Sacher, Ronald A. dan McPherson, Richard A. 2004. Tinjauan Klinis Hasil Pemeriksaan Laboratorium Edisi 11. EGC: Jakarta.

6. Semiadi, G. dan R.T.P. Nugraha. 2004. Panduan pemeliharaan rusa tropis. Puslit Biologi LIPI: Bogor. 